\title{
ИЗУЧЕНИЕ ХИМИЧЕСКОГО И ФАЗОВОГО СОСТАВА ПРОДУКТОВ ПЕРЕРАБОТКИ НЕФТИ И БИТУМА
}

Волков А.И.

ГНЦ ФГУП Центральный научно-исследовательский институт чёрной металлургии им. И.П. Бардина, Москва, Россия rhenium@list.ru

DOI: 10.26902/ASFE-11_151

ЦНИИчермет им. И.П. Бардина в течение многих лет занимается исследованиями технологических процессов извлечения ванадия, никеля из продуктов переработки нефти и битума (зола ТЭС, нефтяной кокс, зола битума, мазут и т.д.). Актуальность работ обусловлена увеличением в переработке доли тяжёлых асфальтосмолистых нефти и битума, вредным воздействием ванадия на технологическое оборудование и катализаторы нефтепереработки, экологическими проблемами, связанными с попаданием тяжёлых металлов в окружающую среду.

Для различных типов нефтегазоносных бассейнов характерно изменение соотношения химических элементов в зольной части. Обработка специальными реагентами для очистки узлов технологического оборудования ТЭС вносит дополнительные элементы в состав золы. Полнота сгорания оказывает влияние на остаточное содержание органической части.

Химический анализ осуществляли с помощью рентгенофлуоресцентного спектрометра $\mathrm{AXIOS}^{\text {max }}$ Advanced фирмы PANalytical (Нидерланды). В исследованных нами образцах золы нефтяного кокса, битума и мазута содержание компонентов составляло, \% масс.: $\mathrm{Na}_{2} \mathrm{O} 0,10$ 4,74; $\mathrm{MgO}$ 0,09-2,14; $\mathrm{Al}_{2} \mathrm{O}_{3}$ 0,61-7,10; $\mathrm{SiO}_{2}$ 0,11-23,00; $\mathrm{P}_{2} \mathrm{O}_{5}$ 0,14-0,53; $\mathrm{S} 0,39-11,21 ; \mathrm{Cl} 0,13-0,23$; $\mathrm{K}_{2} \mathrm{O}$ 0,02-2,04; $\mathrm{CaO} 0,08-4,94 ; \mathrm{TiO}_{2}$ 0,11-,075; $\mathrm{V}_{2} \mathrm{O}_{5}$ 15,18-70,70; $\mathrm{MnO} 0,04-0,42 ; \mathrm{Fe}_{2} \mathrm{O}_{3} 7,15-$ 64,91; $\mathrm{Co}_{3} \mathrm{O}_{4}$ 0,06-4,60; $\mathrm{NiO}$ 1,30-18-59; $\mathrm{ZnO} 0,21-1,99 ; \mathrm{SrO}, 0,03-0,06 ; \mathrm{MoO}_{3}$ 0,06-0,75; $\mathrm{BaO}$ 0,94-1,64; $\mathrm{PbO} 0,04-0,11 ; \mathrm{Cr}_{2} \mathrm{O}_{3} 0,17-0,51$.

Фазовый состав оказывает решающее влияние на состав продуктов пирометаллургической переработки [1]. Так, при восстановлении ванадиевого конвертерного шлака получают ванадийсодержащую лигатуру, но при восстановлении золы алюминием ванадий остаётся в шлаке, а не в металле. С помощью рентгенофазового анализа установлено, что основными фазами шлака, полученного из золы, являются: $\beta$-глинозём $\mathrm{NaAl}_{11} \mathrm{O}_{17}$, периклаз $\mathrm{MgO}$, метаванадат натрия $\mathrm{NaVO}_{3}$, нефелин $\mathrm{Na}_{4-\mathrm{x}} \mathrm{K}_{\mathrm{x}} \mathrm{Al}_{4} \mathrm{Si}_{4} \mathrm{O}_{16}$, замещённый карелианит $\mathrm{V}_{2-\mathrm{x}-\mathrm{y}-\mathrm{F}} \mathrm{Fe}_{\mathrm{x}} \mathrm{Al}_{\mathrm{y}} \mathrm{Cr}_{\mathrm{z}} \mathrm{O}_{3}$. Также присутствуют фазы со структурой шпинели типа $\mathrm{MgAl}_{2} \mathrm{O}_{4}$ и $\mathrm{MgV}_{2} \mathrm{O}_{4}$. Вероятно наличие лепидокрокита $\mathrm{FeOOH}$ и неидентифицированного ванадата щелочных металлов. В некоторых образцах обнаружено значительное количество графита, фаза со структурой граната $\mathrm{Ca}_{\mathrm{x}} \mathrm{Mg}_{\mathrm{y}} \mathrm{Na}_{\mathrm{z}}\left(\mathrm{VO}_{4}\right)_{6}$, форстерит $\mathrm{Mg}_{2} \mathrm{SiO}_{4}$, гематит $\mathrm{Fe}_{2} \mathrm{O}_{3}$, пиролюзит $\mathrm{MnO}_{2}$, диаспор $\mathrm{AlOOH}$, ванадат натрия-магния $\mathrm{NaMg}_{4}\left(\mathrm{VO}_{4}\right)_{3}$.

Исследование золы и шлака методом РФЭС показало наличие в поверхностном слое сульфата железа $\mathrm{FeSO}_{4}$, соединения $\mathrm{V}^{5+}, \mathrm{V}^{4+}$ в шлаке, соединения $\mathrm{V}^{5+}, \mathrm{V}^{4+}, \mathrm{V}^{3+}, \mathrm{V}^{\mathrm{n}+}$, где $0<\mathrm{n}<3$ в исходной золе, $\mathrm{CaO}$ в золе и $\mathrm{Ca}\left(\mathrm{NO}_{3}\right)_{2}$ в шлаке, адсорбированные углеводороды $\mathrm{C}_{\mathrm{n}} \mathrm{H}_{\mathrm{m}}$, органические соединения со связями $\mathrm{O}-\mathrm{C}$ и $\mathrm{O}=\mathrm{C}, \mathrm{Al}_{2} \mathrm{O}_{3}$.

\section{Список литературы}

1. Волков А.И., Кологриева У.А., Ковалев А.И., Вайнштейн Д.Л. Влияние степени окисления и форм элементов в ванадиевом шлаке на технологичность его переработки/ Металлург. 2019. № 8. С. $42-46$.

Работа выполнена при финансовой поддержке РФФИ, проект 18-29-24074 мк. 